\begin{tabular}{|c|c|}
\hline $\begin{array}{c}\text { ÇÜTAD } \\
\text { Çukurova Üniversitesi } \\
\text { Türkoloji Araştırmaları Dergisi }\end{array}$ & $\begin{array}{c}\text { Cilt 5, Sayı } 1 \\
\text { Haziran } 2020\end{array}$ \\
\hline $\begin{array}{l}\text { ISSN: } 2587-1900 \\
\text { E-ISSN: 2548-0979 }\end{array}$ & $\begin{array}{l}\text { Geliş Tarihi: } 20.04 .2020 \\
\text { Kabul Tarihi: } 19.05 .2020\end{array}$ \\
\hline \multicolumn{2}{|c|}{$\begin{array}{l}\text { Makale Künyesi (Tanıtma): Yüceol Özezen, M. (2020). Alan Barnard } \\
\text { Tarinöncesinde Dil. [Tarihöncesinde Dil adlı kitap tanıtımı]. Çukurova } \\
\text { Üniversitesi Türkoloji Araştırmaları Dergisi. } 5 \text { (1), 217-228. }\end{array}$} \\
\hline
\end{tabular}

\title{
ALAN BARNARD / TARİHÖNCESİNDE DİL
}

Muna YÜCEOL ÖZEZEN ${ }^{1}$

Bu kitap², Edinburgh Üniversitesi Güney Afrika antropolojisi profesörü Alan Barnard'in Sosyal Antropoloji ve İnsanın Kökeni (Çeviren: Mehmet Doğan, Boğaziçi Üniversitesi Yayınları, İstanbul 2013) ve Simgesel Düşüncenin Doğuşu (Çeviren: Mehmet Doğan, Boğaziçi Üniversitesi Yayınları, İstanbul 2014) başlıklı çalışmalarıyla başlattığı dizinin üçüncü kitabıdır ve dizinin son halkasıdır. Kendisini bir sosyal antropolog olarak tanıtan ve kariyerinin uzun bir bölümünü bir Güney Afrika avc1-toplayıc1 toplumu olan Naro (Nharo veya Naron) halkı üzerine yapan araştırmacı, Namibya Cumhuriyeti Onursal Elçisi'dir.

$\mathrm{Bu}$ tanıtım yazısında kitapla ilgili değerlendirmeler üç aşamada yapılmıştır: Kitabı Türkiye'de, Türkçe olarak yayımlayan yayıneviyle (Boğaziçi Üniversitesi Yayınevi) ilgili değerlendirmeler, çeviriyle ilgili değerlendirmeler ve kitabın içeriğiyle ilgili değerlendirmeler. Çok az söze gerek duyduğundan ilk ikisiyle başlamak yerinde olur:

Yayıneviyle ilgili değerlendirmem, bu kitabı Türk okuruyla buluşturduğu için teşekkürden öteye gidemez. Ancak şu soruyu sormadan geçmek de pek doğru olmayacak: Kitabın Türkiye'deki baskısında kullanılan kapak resmi ile özgün biçimindeki kapak resmi ${ }^{3}$ birbirinden farklıdır. Özgün metindeki kapak resmi "ilkel" insanlarla ilgili bir simülasyondur ve kitapta bu simülasyonun kime ait olduğu bilgisi yer almamaktadır. Çeviri metinde yer alan kapak resmi, Arjantin'de bulunan Cerro Colorado mağarasındaki bir kaya resmidir ve 1992 'de keşfedilmiştir. Çeviri metinde de kapak resmiyle ilgili herhangi bir bilgi verilmemiştir. Acaba bu iki kapak resmi arasındaki farklılığın nedeni okur olarak bize yansımayan telif sorunları mıdır, yoksa özgün baskıdaki kapak resmi, Türkiye ortamında çok tartışma

1 Çukurova Üniversitesi, Fen-Edebiyat Fakültesi, Türk Dili ve Edebiyatı Bölümü, Prof. Dr. mozezen@cu.edu.tr https://orcid.org/0000-0003-1880-2143

2 Eserin özgün künyesi şöyledir: Barnard, A. (2016). Language in Prehistory, Cambridge: Cambridge University Press.

${ }^{3}$ bkz. EKLER 
götürecek olması bakımından mı değiştirilmiştir? Başlık ve kapak bir kitap için her şey demek değilse de, okurda yarattığı ilk izlenim yönüyle çok şeydir. Buna göre, yayınevi bu ilk izlenim sonucunda doğacak tartışmalardan mı çekinmiştir? Yoksa bu tercihte herhangi bir özel bir amaç yok mudur? Kitapta yayınevinin bu tercihiyle ilgili herhangi bir açıklaması bulunmadığından bütün olasılıkların doğruluk derecesi eşit görünmektedir.

Çeviriyle ilgili değerlendirmem de esasında genel olarak çevirmen Mehmet Doğan'a teşekkürden ibaret olabilir. Doğan, şu ana kadar pekçok önemli ve zorlu kitabı Türkçeye çevirdi. Bu da onlardan biri. Kendisinin bu kitaptaki çevirisini değerlendirebilecek bir İngilizce yetkinliğim yok. Ama kitabı neredeyse bir çırpıda okuyabilmiş ve genel olarak “Acaba burada ne demek isteniyor?” diye bir cümleyi tekrar tekrar okumak zorunda kalmamış olmamı, çeviride "maksadın hasıl olduğu" biçiminde yorumlayabilirim. Tanıtımımı Doğan'ın bu çevirisi üzerinden yaptım. "Bir kitabı özgün dili üzerinden okumak gerek." diyenleri şimdilik duymazdan geliyorum ve aslında her çevirinin yeni bir üretim olduğu gerçeğini aklımda tutarak çevirinin hâla çok önemli bir etkinlik olduğuna ilişkin inancımı sürdürüyorum. Buna rağmen, Doğan'ın örneğin, “Günümüzde konuşan kimsenin hayatta olmadığı, uygun şekilde kayda geçirilmiş bir Kalahari dilini (...)" (s. 60), ifadesini ben olsam, "Günümüzde artık herhangi bir konuşuru kalmamış ve uygun şekilde kayda geçirilmiş bir Kalahari dilini (...)" biçiminde çevirirdim, demekten kendimi alamıyorum. Ama bu tür cümlelerin sayısı çok az ve metnin okunması sırasındaki akıcılığa asla halel getirmiyor. Son olarak Doğan'ın kuram ve hipotez adlarının ilk harflerini büyük yazmasını (özgün metinde nasıl yazılmış olurlarsa olsunlar), "olmasa da olur" kabilinden tercih edeceğimi de belirtmek isterim.

Kitapla ilgili değerlendirmelerime gelince: Barnard, kitabın Önsöz bölümünde, bu üçüncü kitabın aslında yukarıda sözü geçen Simgesel Düşüncenin Doğuşu (bu kavram bir başka sosyal antropolog Claude Lévi-Strauss'a aittir) başlıklı ikinci kitabın "Dilin Çiçeklenmesi” bölümünün genişletilmiş hâli olduğunu belirtmektedir (Buradan da anlaşıldığı üzere kitabın önsöz bölümü de yazarın kendisine aittir.). Bilim insanlarının tarihöncesi dilleri inceleyemediklerini, tarihöncesindeki dillerin günümüzde küçük avc1toplayıcı topluluklarının dillerine mi yoksa çobanlıkla ve tarımla geçinen halkların dillerine $\mathrm{mi}$ daha fazla benzediğini tespit edemediklerini ifade eden araştırmacıya göre, şu anda elden gelen tek şey, tarihöncesi dil hakkında bilebileceklerimizi anlamaya çalışmak, bu dilin nasıl evrimleştiğini, neden evrimleştiğini ve son görünümünü nasıl edindiğini belirlemektir. 
Kitapta Önsöz bölümünü takip eden 8 ana bölüm (1- Giriş, 2Popülasyon Çeşitliliği ve Dil Çeşitliliği, 3- Tarihöncesinde İnsanlar $\mathrm{Ne}$ Yapıyordu, 4- Tarihöncesinde Insanlar Nasıl Düşünüyordu, 5Gündelik Anlatılar, 6- Mitolojik Anlatılar, 7-Cinsel Seçilim ve Dil Evrimi, 8- Sonuçlar ve Gelecek İçin Düşünceler) vardır. Özgün metinde de, çeviri metinde de Iç̧indekiler bölümü, yalnızca bu 8 ana bölümle ve Sözlükçe, Kaynakça ve Dizin bölümleriyle ilgili sayfa bilgisi vermektedir. Kitaptaki bütün alt başlıklar göz önünde bulundurulduğunda ise aşağıdaki gibi bir Iç̧indekiler bölümü ortaya çıkmaktadır ki bu görünüm, kitabın neleri içerdiği, neleri tartışma konusu yaptığıyla ilgili okuyucuya biraz daha ayrıntı sunmaktadır:

1- Giriş

Dilin Başlanglcl

Tarihöncesine Dönelim

Bilimdeki En Zorlu Sorun mu?

Bugünün Sorunlarl

Dilbilgisinin Kökeni

Birkaç Kuram

2- Popülasyon Çeşittiliği ve Dil Çeşittiliği

Avcr-Toplayıcı Etnoğrafyast

İşaretleşmek ve Konuşmak

Dilden Öncesi

Afrika'dan Yaylma

Amerika Kıtalarına Yerleşilmesi

3- Tarihöncesinde Insanlar Ne Yaptyordu

Avcl-Toplayıcı Toplum: On Sekizinci Yüzyıl İcadı mı?,

Homo sapiens'in Genetik ve Kültürel Evrimi

Etnoğrafya Arast

Kuramsal Sapma: Chomsky'e Karşı Foucault

Gerçekliğe Dönüş

4- Tarihöncesinde Insanlar Nasıl Düşünüyordu

İnsan Öncesi” Davranış Örnekleri Olarak Hayvanlar

O Hâlde Hayvan Dilbilgisi Söz Konusu mu?

Denisovalılar, Neandertaller ve Homo sapiens

Antropologlar Nasıl Düşünüyor?

Biyolojik Ihtiyaçlar ve Kültürel Karşllıklar

Ekolojik ve Kültürel Modeller

Kültürün İtirazı

Ters Masifaya Karşı Optimal Yiyecek Arama

5- Gündelik Anlatılar

Dil ve Düşünce

Ritüelin Önemi

Öğ̈̈nler, Filizler, Yapraklar 


\author{
Başlangıçta Diller Vardı \\ Norm Olarak Çokdillilik \\ Başka Değişim ve Çokdillilik Örnekleri \\ Dilsel Görelilik Hipotezi \\ İşaret Keyfî Değil mi? \\ 6- Mitolojik Anlatılar \\ Mitin Anlamı \\ Mitoloji Düşüncesi \\ Seechelt Miti Üzerine Düşünceler \\ Dansll Ibadet mi? \\ Mit Kuramlarl ve Dilin Amacl \\ Vatoz ve Güney Rüzgârl \\ Nihayet, Jungcu Arketipler \\ O Zamanlar Dil Vardl \\ 7- $\quad$ Cinsel Seçilim ve Dil Evrimi \\ Neandertallerle Sevişmekten Şefkate: Dilsel Seçilim mi? \\ Kuramsal Kökenler: Zihne Dönüş \\ Kalahari Kökleri \\ Tarihöncesi Teknolojileri \\ 8- Sonuçlar ve Gelecek Iç̧in Düşünceler \\ Sosyal Antropoloji ve Dilin Ortaya Çıkışı \\ Antropoloji ve Çelişki \\ Antropoloji Bilimleri Yeniden Birleşecek mi? \\ O Hâlde Ne Ögrendik? \\ Özetleyelim
}

$\mathrm{Bu}$ ana ve alt bölüm başlıklarından insanın ve dolayısıyla da dilin kökeni sorununun birbirinden bağımsız tartışma ve değerlendirmelerle ele alındığı anlamına gelmemektedir ${ }^{4}$. Tam tersine hemen hemen her ana ve alt bölümde soruların, bunlarla ilgili olası cevapların, değerlendirmelerin ve yorumların zaman zaman tekrarlandığı dikkati çekmektedir. Buna göre yazar, tartışma ve değerlendirmeleri sarmal bir görünümde okuyucuya sunuyor: İnsan ama kime İnsan diyelim, yalnızca konuşabilenler mi İnsan'dır? İyi ama kimdi bu ilk konuşanlar? Neandertaller konuşabiliyor muydu? Dil ama dil'den neyi anlıyoruz, jestlerle ve işaretlerle ve konuşmaksızın anlaşmak da dil midir? Dil yalnızca iletişim kurmak için mi vardır, öyle ise iletişim kuran hayvanları veya insanın diğer iletişim yollarını nereye oturtmak gerekir? Yoksa dil bilgi üretmek, bilgi aktarmak, mitleri ve mecazları yaratmak için mi vardır, kısacası dil "kültür" yani "biriktirilen bilgi"

${ }^{4} \mathrm{Bu}$ bu soruların genellikle birbirinden ayrilamaması, antropoloji ve dilbilimi birlikte hareket etmeye zorlamaktadır. Zaten dilbilimsel antropoloji disiplini de bu zorunluluğun sonucunda ortaya çıkmıştır. 
ve "öğrenilen davranış" mıdır? İnsan gruplar hâlinde yaşamasaydı yine de dili üretir miydi? Başka bir deyişle, dil aslında toplumsal örgütlenmenin ve işbirliğinin mi bir ürünüdür? İk-dil, kök-dil, çekirdek-dil var mıdı, varsa bu kök-dili bugün kimlerde bulabiliriz? Günümüzde hâla var olmaya devam eden avcı-toplayıcılar ilk dil için model olabilirler mi? Avcı-toplayıcı gruplar (ki sayıları ortalama 25’tir, R. Dunbar’a göre en fazla 150) neden çokdilliydiler ve hâlihazırda neden çokdilliler? Dil bir içgüdü müdür? Chomsky ve Pinker dilin biyolojik bir olgu olduğu konusunda haklılar mı (yoksa değiller mi, yoksa dili daha çok kültürel bir olgu olarak gören Evans ve Tomasello mu haklılar veya yoksa biyolojiyle kültürü birleştiren Bickerton $\mathrm{m} 1$ hakl1)? Insan diliyle birlikte yavaş yavaş $\mathrm{m}$, ani bir biçimde mi yoksa hem ani hem aşamalı bir biçimde evrimleşti? Dil tam bir bir evrimin mi yoksa basitçe bir İnsan türünde, hatta bir insanda tesadüfen yaşanan bir mutasyonun mu (FoxP2 mutasyonunun) ürünüdür? Başlangıçta tek bir dil mi vardı? Dil aileleri mi yoksa aynı coğrafyayı paylaşan farklı grupların dillerinin birbirine zamanla benzemeye başlamasıyla ortaya çıkan dil birliği mi demek daha doğru olur? Ilk-dil ve ilkellerin dili basit miydi yoksa karmaşı mıydı? Günümüz çağdaş toplumlarının dili giderek basitleşti mi (en azından semantik olarak ve dilbilgisel kategoriler bakımından)? Başlangıçta yalnızca sözcük mü / isim mi vardı? İyi ama cümleler nasıl ve ne zaman ortaya çıktı? Dilin ortaya çıkmasında akrabalık ilişkileri mi, cinsel seçilim mi (hikâye anlatabilen bir eş daha hayırlı bir kısmet midir) yoksa tesadüfler mi etkili? Mit, din ve müzik insanın ve dilinin evriminin neresinde? Insan türü veya türleri dünyaya nasıl yayıldılar? Antropoloji disiplini bütün bu sorular karşısında bir bütünlük arz ediyor mu gibi sorular ve bu konulardaki değerlendirmeler her sayfada okuyucunun karşısına çıkıyor, hem de geniş bir literatürle. Ancak hemen belirtmek gerekir ki sorular öylesine önemli, cevapları ve olasılıkları düşünmek öylesine keyifli ki tekrarlar okuyucuyu yormuyor hatta bir gereksinime dönüşüyor.

Bununla birlikte, Barnard, kitabın son bölümünde geniş literatür bilgisini bir kenara bırakıyor, kendi görüşlerini daha çok öne çıkararak bizimle sonuçlarını ve gerekçeli önerilerini paylaşıyor ve bu son bölümdeki $\mathrm{O}$ Hâlde Ne Ögrendik ve Özetleyelim alt başlıklarıyla okuyucunun anlamasını beklediği şeyleri özetliyor. Genel hatlarıyla şöyle diyor Barnard:

\section{O Hâlde Ne Öğrendik (s. 163-166)}

Dilin nasıl, ne zaman doğduğunu tam olarak biliyor muyuz? Hayır, tam olarak bilmiyoruz. Fakat atalarımız ve Neandertaller kesinlikle buna meyilliydiler. FoxP2 mutasyonu bunlardan biridir. 
Ama insan dilini yalnızca bu mutasyonla açıklamak olanaksız. Diğer mutasyonlar henüz keşfedilmedi. Dilbilgisinin icadı muhtemelen hızlıydı; gruplar birbirine temas ettikçe, gruplar arası evlilikler arttıkça, diller evrimleşip birbirine karıştıkça dilbilgisi kategorileri de tekrar tekrar değişip yenilendi. Peki bu ne zaman ortaya çıktı? Muhtemelen simgesel düşünceyle. Ama ritüelin, müziğin, sanatın yaratılmasıyla birlikte gelişti, mitolojide ve başka anlatı biçimlerinde tepe noktasına ulaştı. Bu en erken 130.000 yıl önce gerçekleşti, tam oluşum ise 74.000 yıl önce meydana geldi. Bu insanların Afrika'dan bütün dünyaya yayılmalarından hemen önce oldu. $\mathrm{Bu}$ tarihler, Chomsky'nin kafasındaki 100.000-60.000 yil tarihlemesinden erkendir. Homo sapiens gibi muhtemelen Homo neanderthalensis de konuşabiliyordu, Homo heidelbergensis'in ve Homo denisova'nın da konuşuyor olması muhtemeldir. Yani iletişimin sese dökülmesi bundan 350.000 yıl öncesinden de başlamış olabilir. Ama bu diller yine muhtemeldir ki modern insanın konuştuğu dillere benzer diller değildi.

İlk-dil neydi? Bilmiyoruz. Zaten bu soru baştan yanlış. Diller neredeyse en başta harmanlanmış bir görünümdeydi. Kırma bir dil icat edilir, bu çocukların dili olur, hızla kırma anadile dönüşür, yayılır, evrimleşir, yeniden harmanlanır. Dillerin dilbilgisel karmaşıklığı elde etmesi yavaş olabilir, hızlı olabilir, ama süreklidir. Bir ilk-dil var idiyse bile buna çok kısa zamanda başka diller eşlik etmiştir. İlkel avc1-toplayıc1 gruplarda çokdillilik bir normdu. Homo neanderthalensis'in beyni Homo sapiens'ten büyüktü, bu bakımdan muhtemelen onlar da çokdilliydi (Bu noktada beyin hacminin, esasında insan olmada veya "doğal insan dili" denilen sentaktik dili üretmede birincil bir parametre olmadığını hatırlamak yerinde olacaktır. Esasında hiçbir parametre doğal insan dilini açıklamaya tek başına yetmiyor. Burada yine Barnard'a kulak vermek gerek: "Gerçek genellikle arada bir yerdedir.”)

Toplum hangi biçime kavuştu? Avcı-toplayıcılar göçebe değilseler de hareketlidirler, mevsimden mevsime yer değiştirirler. Avc1-toplayıcılar her kıtadalar, ama dilin güney ya da doğu Afrika'da doğmuş olması ihtimali yüksek. İlk avc1-toplayıcılar, günümüz avc1toplayıcıları gibi çok çeşitli sebzeler ve et yiyorlardı. Alet yapıyorlardı. İşaretleşiyor ve konuşuyorlardı. Becerikliydiler, yaratıcıydılar, ama kaynakları biriktirmek yerine boş zaman biriktirmeyi tercih ediyorlardı. Paylaşıyorlardı, hediye alıp veriyorlardı, mallarını borç olarak verebiliyorlardı. Bütün bunlar iletişimi gerektirir. Mitler, hikâyeler anlatıyorlardı, bunların doğruluğuna bakmıyorlardı, uydurup uydurup yeniden anlatıyorlardı. Hele bu bayağı üstün bir dil becerisi gerektirir. Bu dil becerisi 
başlangıçta nasıldı? İnsanın kendi kendisiyle konuştuğu bir iç-dil (idil) mi, başkalarıyla iletişim kurduğu bir dış-dil (d-dil) mi? İnsanlar anneleriyle iletişim kurmaya başlar başlamaz bir d-dil edinir. Böylece düşünme yetisi de edinir (Barnard burada dilin düşünceden önce var olduğunu ima ediyor. Ama öncesinde bu konudaki fikrini açıkça ortaya koymuştu: "Dil aracılığıyla düşünüyoruz ve işin bu yanını anlamamız şart.” (s. 28).).

Barnard, O Hâlde Ne Öğrendik bölümünü bitirirken okuyucuyu gene kitabı ilk eline aldığı noktaya götürüyor ve özetle şöyle diyor (s. 165-166): Dilin kökenine ilişkin doğru soruları soruyor muyuz? Neredeyse, her araştırmacının dilin nasıl ve ne zaman doğduğuyla ilgili bir kuramı var. Kuramlar çok ve çoğu zaman birbirine karşıtt. Ama şu söylenebilir: Dil tek seferde ortaya çıkmadı, önce bir kök-dil oluştu, sonra sözcükler kullanıldı, söz düşünceye dönüştü, dil evrimleşti, dilbilgisi karmaşıklaştı, kırma diller ortaya çıktı, dağılıp gitti, sonra tekrar tam dillere dönüştü. Bu süreç hep yaşandı, hâla yaşanıyor. Dilin kökeninin tarihöncesine dayandığı kesin? Ama ne zaman? İşte bu "başlangıç noktası" sorunu, neredeyse bilinemez bir zorluk taşıor.

\section{Özetleyelim (s. 166-168)}

1- Dil evrenselleri var, dolayısıyla dil modern insanlar dünyaya yayılmadan önce ortaya çıktı. Türümüz Avustralya'ya göç ettiğinde zaten bir dilleri vardı (Kitap boyunca Avustralya'ya yerleşilen tarih olarak 65.000 yıl öncesi tahmini paylaşılıyor. Ama ne hikmetse, bu grubun dünyanın geri kalanıyla bağı son birkaç yüzyıl öncesine kadar kopuk kalmış.). Değişik kıtalara yayılmada dilden yararlanılmıştır.

2- $\quad$ Homo sapiens sapiens doğu veya güney Afrika'da çoğaldı ve buradan yayıldı, hem de diliyle birlikte. Yayılmaya başladığında zaten bir dili vardı.

3- Bir zamanlar dünyada bugüne oranla çok daha fazla dil vardı. Kırma dillerin kırma anadile, ardından karmaşıklaşıp dile dönüştüğüne sonra da basitleştiğine yönelik elde bolca kanıt var.

4- Biz bugün genel olarak tekdilliyiz, okuma yazma biliyoruz ve büyük gruplar hâlinde yaşıyoruz. Atalarımız ise avc1-toplayıcıydı, çokdilliydiler, sözlü bir kültürleri vardı ve küçük gruplar hâlinde yaşıyorlardı. Gruplar arasında evlilikler oluyordu. Böylece gruplar birbirlerine hem genlerini hem dillerini aktarıyorlard1.

5- $\quad$ Maddi kültürün gelişmesi ve simgesel kültür birikiminin yeni kuşaklara aktarılmasıyla birlikte teknolojik karmaşıklık da arttı. 
Eski Taş Çă̆ı yerini Orta Taş Çağı'na o da yerini Yeni Taş Çağı'na bıraktı (Bu Barnard'ın özet bölümündeki makro bakışının bir ürünüdür. Yoksa kendisi kitap boyunca, örneğin, dünyada bir coğrafyada Orta Taş Çağı'na girilirken bir coğrafyada daha uzun binyıllar Eski Taş Çağı'nın yaşanabildiğini de söylüyor.). Dil Orta Taş Çă̆ı'nın belki başında ama en geç sonunda oluşmuştur.

6- Mitoloji insanın yerleştiği her yerde var, hatta çoğunlukla ortak. Mitlerin dolambaçlı ve "olağanüstü" yanı insan olmanın bir parçası. İnsanlar mitler aracılığıyla düşündü ve düşünme işini Orta Taş Çağı'nda simgesel kültürü yaratmasıyla yaptı. Mit, simgecilik, sanat, din ve daha birçok şey dili yaratmıştır (Bence bunlar hem dili yaratmıştır hem de dilin ürünleridir. Başka bir deyişle, hem sebep hem sonuçturlar.).

Barnard'a göre mitoloji dilin kökeni arayışlarında iyi bir başlangıç noktasıdır ve mitoloji ve sosyal antropoloji alanı birbirlerinden katkı alırlar (Kendisinin, bu yüzden olsa gerek, kitap boyunca 25 göndermeyle, en çok gönderme yaptığı kişi C. LéviStrauss.). Acaba avc1-toplayıcılarda daha "gerçekçi" hikâyeler mitolojiden önce mi gelirdi, sorusu cevaplanamiyor. Ama bugünkü avcı-toplayıcı grupların bazılarında (örneğin Naro halkında) iki tür anlatı arasında fark yoktur (Ben de nedense, mitlerin "gerçekçi" hikâyelerin öncülü oldukları düşüncesindeyim. Konunun uzmanı olmayınca ahkam kesmek kolay!).

Dilin evrimi için 4 kilit: mutasyon, çokdillilik, mit (cinsel seçilim mite dahil edilebilir) ve göç. Bazıları buna beşincisini ekliyor: farkindalık.

Avc1-toplayıcılar başlangıçta peşin getiri ekonomisine sahiptiler: Önceden plan yapmıyorlar, hemen tüketiyorlar ve biriktirmiyorlardı. Sonradan vadeli ekonomiye geçtiler: Plan yaptılar, biriktirdiler, başka türlü de düşünebildiler. Aslında vadeli getiri ekonomisi daha çok tarıma geçen insan gruplarının bir tercihiydi. Yani insanlar (hatta bundan önce hayvanlar) son 10-11.000 yıl öncesine kadar büyük oranda peşin getiriye dayalı olarak yaşadılar. Bugün hiçbir insan grubunda temsil edilmiyorlar. Hatta günümüzün avcı-toplayıcıları bile artık biriktiriyor, plan yapıyor. O hâlde, dili üreten insanlar bizim gibi değillerdi veya bize dönüşmeye başlarken dili ürettiler. Dilin oluşumu bisiklet sürmeye (Barnard, T. Ingold'un bu görüşünü S. Pinker'ın örümcek ağı örneksemesine karşıt olarak savunuyor) benzer: $\mathrm{Ne}$ tamamen içuüdüdür, ne de tamamen icattır [sonradan öğrenmedir], ikisinden de birşeyler barındırır (Barnard bu son yargısıyla, okuyucunun cevabını çok merak ettiği bu soruyu neredeyse cevapsız bırakıyor, adeta hevesini kursağında bırakıyor. Ama bu "arada"lık, 


ÇÜTAD
Haziran 2020 Alan Barnard / Tarinöncesinde Dil

bilimsel sorumluluktan kaynaklanıyor. Dil çok soyut bir şey ve şimdilik "arada" olmak iyidir.)

Kitap, ana bölümlerden sonra gelen bir Sözlükçe bölümüyle, son derece zengin bir Kaynakça bölümüyle devam etmiş ve kavram ve kişi adlarının yer aldığı bir Dizin bölümüyle tamamlanmıştır. Araştırmacı Sözlükçe bölümünü şöyle gerekçelendirmiştir: “(...) bu sözlükçe kendi başına da okumaya uygundur, bu anlamda, dilin yaratılma amaçlarından birine hizmet ettiğini düşünüyorum: yaratıcı düşünceyi olanaklı kılmak, yaratıcı düşünce sürecini kolaylaştırmak." (s. 13). Dizin bölümü ise başka birçok bakımlardan olduğu gibi dil kuramları bakımından da yararlı, ancak kitapda adı geçen bütün kuramlar, hatta bunların çoğu Dizin'de yok. Barnard, dilcilerin genel olarak dilin kökeni gibi zorlu bir soruyu bir kenara bırakıp daha çok yapı çözümlemelerine ve teknik konulara odaklanmalarını çok anlamlı bulmadığını ima ediyor (s. 26). Kitabın dil kuramları ve varsayımlarının genel çerçevesi geniş. Bu çerçeve şöyle (Bir dilci olarak bu kuramların özellikle ilgimi çekmesi, sanırım anlaşılır bir durum):

Ağaç Bitiştirme Dilbilgisi (s. 26), Ahlakî Duygular Kuramı (s. 25), Anlatı Kuramı (s. 75), Avlanma Kuramı (s. 75), Bağıntısal Dilbilgisi (s. 26), Baş-Sürümlü Öbek Yapısı Dilbilgisi (s. 26), Dilbilgileşme Kuramı (s. 99), Dil Değişimi Hipotezi (s. 113), Dilsel Görelilik Hipotezi (s. 115), Evrensel Dilbilgisi Kuramı (s. 26, 102, 160, 173, 175), Genelleşmiş Öbek Yapısı Dilbilgisi (s. 26), İlkeler ve Parametreler Kuramı (s. 26), İşlev Kayması Kuramı (s. 75), Jest Kuramı (s. 80), Jest Modeli (s. 17), Kategorik Dilbilgisi (s. 26), Kemer Dolgusu Kuramı (s. 75), Memetik Kuramı (s. 75), Müzikal Hipotez (s. 17), Sapir-Worf[çu Yaklaşım] (s. 17, 18, 25, 112, 115, 145, 160, 161, 186), Sözlüksel-İş̧levsel Dilbilgisi (s. 26), Sözlük Modeli (s. 17), Standart Kuram (s. 26), Taklitçilik Modeli (s. 17), Tomasello[nun Bilişsel Yaklaşımı] (s. 30), Yetinmeci Çizgi (s. 26), Yiyecek Arama Kuramı (s. 75, 95), Yönetim ve Bağlama Kuramı (s. 26).

Bunlar açık adlandırmalarla ortaya çıkan çerçeve. Örtük göndermeler ve imalarla çerçeve daha da genişliyor: J. Locke, J. G. Herder, J. J. Rousseau, W. Von Humboldt, A. Wray, D. Bickerton, T. Ingold, S. Mithen, S. Pinker, S. Levinson, M. Foucault, R. Englefield, V. Evans, G. S. Kirk, J. L. Dessalles, M. Müller, M. Edwardes, G. Miller ve diğerleri.

İnsan dili kuşkusuz yalnız dilbilimcilerin değil, bütün sosyal bilimcilerin (tarihçilerin, antropologların, etnologların, psikologların, sosyologların, arkeologların vb.), hatta yer yer doğa bilimlerinin 
(biyologların, etologların, nörologların, genetikçilerin vb.) ve matematikçilerin bile ilgisini çeken bir konudur (Zaten Barnard de kitabı boyunca neredeyse bütün bu alanlardan literatür paylaşıyor bizimle.). Ancak, dilin nasıl oluştuğu veya nasıl doğduğu (ilki konuya evrimsel, ikincisi rasyonal bir bakışla bakmak demektir), bütün dillerin atası olabilecek bir veya birkaç kök-dilin (çekirdek-dilin) olup olmadığı gibi köklü soruların dilbilimcilerden çok diğer alanların uzmanlarının ilgisini çekiyor olması ve dilbilimcilerin "dile gelmiş" olana odaklanıp enerjilerini ve zamanlarını daha çok yapısal çözümlemelere ayırması dikkate değerdir. Dilbilimcilerin bu ağırlıklı tercihleri, insan diline yönelik bu en büyük ve en zor soruları başka alanların uzmanlarına bırakmaları, aslında sorunun çoğunlukla görmezden gelinmesi biçiminde yorumlanabilir. Son yıllarda özellikle Caner Kerimoğlu'nun yaptığı çalışmalar (özellikle Dilin Kökeni Arayışları yazı dizisi, yakında basılacakları bilgisini aldığımız Neandertaller Konuşur muydu? ve Dilin Evrimi / Evrimin Dili kitapları gibi) bir kenara bırakılacak olursa, bu ilgisizliğin Türkiye’de çok daha ileri boyutta olduğu tahmin edilecektir. Çünkü bu, daha sorulduğu ilk andan itibaren, başka birçok disiplinden veriye gereksinim duyulan, daha önemlisi araştırmacının bütün değer yargılarından ve anlam dünyasından bağımsız olarak ele alınması gereken, çoğu zaman araştırmacının düşünce evreninde köklü değişimlere neden olan ("köklü değişimleri sağlayan" mı demeli?) bir sorundur. Alan Barnard kitabında tam da bunu yapmış ve verilerin kendi düşünce dünyasında yaratabileceği bütün köklü değişsimlere açık ve hazır bir tavır takınmıştır. Böylece kendisi, çok çeşitli bilimsel disiplinlerden elde ettiği veriyle, son derece nesnel bir biçimde tarihöncesindeki dil üzerine gerçekçi ve akılcı varsayımlar öne sürmüştür. Ona göre, avc1-toplayıcılar düşünsel açıdan modern insan kadar gelişkindirler, nasıl iletişim kurarlarsa kursunlar modern insanlığın büyük bölümüyle aynı çizgide düşünmüşlerdir ve sapiens'e gelmeden çok çok önce bütün Homo türlerinde bir dil biçimi vardır. Ona göre, günümüz dillerinin üstünlük yarışları bir yana, tarım toplumlarının veya elektronik toplumların dilleri bile bir avcı-toplayıcı halkın dilinden üstün değildir.

Barnard, sıklıkla dilin onunla oyunlar oynayarak değiştiğini, dil oyunlarını da en çok çocukların yaptığını vurguluyor (s. 153). Bu durum okuma-bilmeyen toplumlarda daha yaygın. Ben kişisel olarak bu süreçte çocuklardan çok gençlerin etkili olduğunu düşünüyorum: Büyüklerden farklı algılıyorlar, farklı düşünüyorlar, bu yüzden de "bozuyorlar", yaratiyorlar, yeniden üretiyorlar. Tam bu noktada, Türkoloji dünyasında, hatta dil uzmanı olmayan kişiler arasında (Nedense ülkemizde dil üzerine konuşmak için dil uzmanı olmaya gerek yokmuş gibi bir algı var. Deyim yerindeyse, dil, "ağzı olanın 
konuştuğu", kendinde konuşma hakkı gördüğü bir alan.) sık sık duyduğumuz "Gençler dili bozuyor." sitemini hatırlamak ve çocukları ve gençleri, dilbilgisi bir yana, imlaya sıkıştırmanın onların bu yaratıcılık süreçlerini nasıl etkilediğine kafa yormak gerekiyor. Kastettiğim, doğal bir seyirle dil yasalarının işlediği ve aslında kaçınılmaz olan değişimlerdir, dil yasalarından çok dildışı yasaların işlediği ve doğal sınırları aşan değişimler değil. İtibar kavramının merkezine Osmanlı döneminde önce Arapçanın sonra Fransızcanın, günümüzde ise İngilizcenin oturtulmasında dil yasalarından çok toplumbilim ve ruhbilim yasalarının işlediği çok açıktır. Tabii dilin toplumdan ve bireyin ruhundan tamamen bağımsız olup olmadığı konusu ayrıca tartışmaya değerdir.

Dilin kökeni tartışmasına tekrar dönersek: Ben bir okur ve bir dilci olarak, insan evrimi gözümüzün önünde gerçekleşmediğinden, bu evrim zamansal olarak çok derinlere gittiğinden, en başarılı rekonstrüksiyon bile bizi en fazla 8.000 yıl öncesine götürebildiğinden (s. 142) ve dil araştırmalarında arkeolojide olduğu gibi radyokarbon bir tarihleme yapamadığımızdan, düşünmeye, tahmin etmeye, varsayımlar üretmeye devam etmenin kaçınılmaz olduğunu düşünüyorum. Ama bu süreçte gözlemlenebilme güçlügü yüzünden onun "verili" bir şey olduğunu düşünmek (rasyonalist dilbilimci A. N. Chomsky yaklaşımı) veya bir içgüdü olduğunu savunmak (ruhbilimci S. Pinker yaklaşımı) yerine, onun bilişsel olarak gözlemlenebileceği (evrimci antropolog M. Tomasello yaklaşımı), otomatik olarak ve zahmetsizce ortaya çıkan bir şey olmadığı (bilişsel dilbilimci V. Evans'ın yaklaşımı) ve çevreyle etkileşimimizin bir ürünü olduğu (ruhbilimci B. F. Skinner yaklaşımı) motivasyonuna sahibim. Şimdilik! Öyle görünüyor ki dili anlamak için gidecek daha çok yolumuz var. Alan Barnard bu süreçte çok iyi bir yol arkadaşı değil yalnızca, çok da iyi bir kılavuz.

\section{KAYNAKÇA}

Barnard, A. (2019). Tarihöncesinde dil (Mehmet Doğan, Çev.). İstanbul: Boğaziçi Üniversitesi Yayınları. 
ÇÜTAD

Haziran 2020

Alan Barnard / Tarinöncesinde Dil

\section{EKLER}

Özgün Kapak

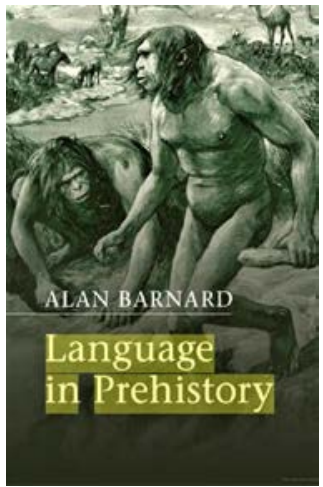

Çeviri Kapağı

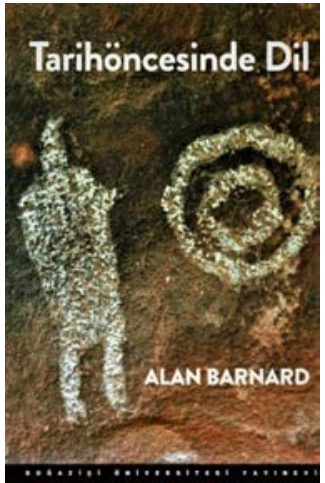

